\title{
Da Odisseia À Odisseia de PenÉlope: O CORO DE ESCRAVAS COMO PORTA-VOZ DA Alteridade, ViolÊNCIA E REDEnÇão
}

\author{
From the Odyssey to the Penelopiad: \\ the Chorus of maids as spokesman for \\ alterity, violence and redemption
}

Sigrid P. M. L. S. Renaux*

Se a crítica feminista, como uma das atuais vertentes da crítica literária, assumiu o papel de "questionadora da prática acadêmica patriarcal" (ZOLIN, 2005, p. 181), A Odisséia de Penélope: o mito de Penélope e Odisseu de Margaret Atwood (2005) projeta este questionamento de duas maneiras distintas, mas complementares. A primeira, ao Atwood, em seu diálogo crítico-intertextual com a Odisséia, contestar e acusar o "lugar e a autoridade da posição masculina” (BUTLER, 2003, p. 7-8), tão aparente na natureza patriarcal da mitologia grega e concretizada na épica homérica, entre outros, no episódio das doze escravas enforcadas a mando de Odisseu, instigandoa assim a reescrever a história de Penélope e de suas escravas baseando-se em outras versões míticas. Nesta reescritura, dando voz à Penélope e às escravas a fim de resgatar aspectos não revelados nos textos homéricos, Atwood o faz de um ângulo inusitado: por um lado, Penélope narra sua própria história após quase três mil anos no Hades e, portanto, dialogando de sua perspectiva do século XXI - observadora, irônica e sutilmente feminista - com a perspectiva homérica. Por outro, as escravas formam um Coro, que canta, declama e dança enquanto também relata sua verdadeira história: um relato que expõe sua alteridade como sinônimo de condição objetal e de identidade em falta, condição essa que as deixava expostas a todo tipo de violência, levando assim a sua condenação por parte de Odisseu ao retornar a Ítaca - por as considerar infiéis a ele, como senhor - e a sua

* UNIANDRADE 
consequente execução por Telêmaco. Como Atwood comenta na Introdução,

Optei por entregar a narrativa a Penélope e às doze escravas enforcadas. As escravas formam o Coro, que canta e declama, concentrando-se nas duas questões que se destacam numa leitura atenta da Odisséia: o motivo do enforcamento das escravas e o real propósito de Penélope. A maneira como a história é contada na Odisséia não convence, há muitas incoerências. Sempre vivi assombrada pelas escravas enforcadas; em $A$ odisséia [sic] de Penélope, ocorre o mesmo com Penélope. (ATWOOD, 2005, p. 12) ${ }^{1}$.

Assim, bastaria a Atwood, ao compor A Odisséia de Penélope, ter dado voz a Penélope, como figura mítica e épica, mas simultaneamente pós-moderna, para recontar sua história, refletindo, entre outros, sobre sua alteridade como mulher - filha e esposa de reis -, a fim de desmitificar a imagem homérica do "ardiloso Odisseu". Entretanto, Atwood torna ainda mais contundente esta desmitificação ao entremear a narrativa de Penélope com a voz de suas escravas que, em contraponto paródico, além de desconstruir a imagem de Odisseu, de Telêmaco e do patriarcado vigente na época homérica, tornam mais ambígua e complexa a figura da própria Penélope, ao lançarem dúvidas sobre suas verdadeiras intenções: não mais apenas como a figura idealizada na Ilíada e na Odisséia, mas também como eventualmente culpada pelo enforcamento delas, a fim de resguardar perante os outros sua imagem de rainha virtuosa.

Este conteúdo instigante, por sua vez, encontra-se ainda mais ressaltado pela forma narrativa em que é escrito, o que nos leva ao segundo questionamento de Atwood sobre o lugar e a autoridade da posição masculina: a forma narrativa da autora desconstrói e subverte não apenas o gênero épico, ampliando-o e adaptando-o a sua própria época - a da pósmodernidade, com suas convenções culturais e sociais - ao tornar uma história não ilustre o assunto da epopeia: a narrativa de uma mulher, mesmo sendo rainha; vinculado não a cometimentos bélicos, mas à vida de Penélope desde seu nascimento até o retorno de Odisseu vinte anos após seu casamento; e, concomitantemente, ao entremear os episódios da narrativa de Penélope com os de suas servas, que também narram e comentam suas histórias anônimas, plebeias e, portanto, desprezíveis -, vinculadas aos atos vis cometidos contra elas desde a infância até seu enforcamento e sua posterior perseguição a Odisseu (RENAUX, 2008, p. 8).

Subverte, simultaneamente, o meio expressivo da poesia épica caracterizado pelo emprego do hexâmetro dactílico como estrutura métrica página da citação.

Todas as próximas referências à obra serão apresentadas como $O P$, seguidas do número da 
mais conveniente -, ao introduzir, além da prosa nos capítulos narrados por Penélope, também outras formas literárias e composições poéticas nos capítulos cantados, declamados ou narrados pelo Coro: não apenas rimas, canções, idílios, baladas, mas até uma elegia em prosa, um drama em verso, uma aula de antropologia e o julgamento de Odisseu gravado em vídeo. Esta utilização de diferentes formas literárias, como será visto, irá valorizar e caracterizar a fala das escravas, como vítimas e porta-vozes da alteridade, ao elas exigirem vingança e continuarem a perseguir Odisseu através dos séculos. Assim, essas diferentes formas literárias desconstroem o estilo épico ao fragmentá-lo numa série de gêneros menores da época e também da atualidade, tornando-o híbrido, caracterizando ao mesmo tempo uma voz feminina que se contrapõe à voz patriarcal da épica homérica.

A fim de podermos traçar o percurso desta Odisseia feminina ocultada pela homérica e detalharmos de que maneira se concretiza no texto este duplo questionamento de Atwood, iremos fazer uso de alguns conceitos operatórios básicos da crítica feminista, tais como:

- Patriarcalismo: organização familiar originária dos povos antigos, na qual toda instituição social se concentrava na figura de um chefe, o patriarca, cuja autoridade era preponderante e incontestável (ZOLIN, 2005, p. 183).

- Alteridade: termo que se refere "ao outro engajado num contexto político, cultural, religioso e lingüístico" (BONNICI, 2007, p.19). Ainda dentro deste conceito, a dialética da identidade concebida como núcleo e da alteridade como uma 'exterioridade', orbitando ao seu redor, quando trazida para o mundo das relações de poder na sociedade patriarcal, fez o núcleo caber ao homem, "senhor da razão, da lei, da religião e proprietário de riquezas" e a periferia, à mulher, expropriada desses atributos. Assim, a partir desse contexto, foi atribuída uma alteridade à mulher, como sinônimo de condição objetal e de identidade em falta, e não de uma alteridade autêntica, intersubjetiva (WADDINGTON apud ZOLIN, 2005, p. 183).

- Mulher-sujeito: marcada pela insubordinação aos paradigmas estabelecidos pelo patriarcalismo, por seu poder de decisão, dominação e imposição, enquanto a mulher-objeto é definida pela submissão, pela resignação e pela falta de voz (ZOLIN, 2005, p. 183).

- Gênero: relação entre os atributos culturais referentes a cada um dos sexos e à dimensão biológica dos seres humanos e, portanto, como categoria que implica diferença sexual e cultural (ZOLIN, 2005, p 182).

O texto da Odisséia de Penélope, após a epígrafe e a Introdução, apresenta-se dividido em vinte e nove capítulos, dos quais dezoito são narrados por Penélope e, entremeados a eles, os outros onze são apresentados pelo Coro de escravas. Entretanto, mesmo que nosso objetivo seja priorizar 
a função do Coro de escravas como porta-voz de sua alteridade, violência e redenção, esta análise não pode ser desvinculada do relato de Penélope, pois lhe serve de complemento e contraponto paródico, como já mencionado.

Assim, no capítulo I, "Uma arte menor", Penélope, como habitante dos campos elíseos, morada dos virtuosos no Hades, inicia sua história como narradora autodiegética ressaltando a figura de Odisseu: suas mentiras, esperteza, astúcia e falta de escrúpulos, enquanto ela fingia não ver nada, pois queria "um final feliz". Entretanto agora, após três mil anos, percebe que chegou sua vez de tecer sua "própria narrativa", mesmo que "contar histórias" seja "uma arte menor", a fim de se defender das zombarias e dos "mexericos escandalosos" que circulavam pelo mundo a seu respeito (ATWOOD, 2005, p. 17).

Este lado obscuro e avesso da figura de Odisseu torna-se ainda mais tenebroso com a introdução do Coro de escravas, no Capítulo II, no qual elas se apresentam, em contraponto, numa canção que parodia seu próprio enforcamento, pois é uma "canção de pular corda"2, já acusando Odisseu pela sua morte, acusação esta que irá se tornar um leitmotif nesta obra:

\author{
we are the maids \\ the ones you killed \\ the ones you failed \\ we danced in air \\ our bare feet twitched \\ it was not fair [...] \\ Enquanto isso, ele se divertia \\ with every goddess, queen, and bitch \\ from there to here \\ you scratched your itch (ATWOOD, 2005/a, p. 5)
}

Elas ressaltam em seguida a força dos binômios sexo/poder e senhor/escrava, ao afirmar "you had the spearlyou had the word/at your command", a lança como simbolo fálico e a palavra como símbolo do privilégio masculino confirmando o poder do rei como sexo e poder sobre as escravas. E, após rememorarem o serviço humilhante a que foram submetidas depois da matança dos pretendentes por Odisseu

\footnotetext{
2 Optamos por apresentar o texto desta canção em inglês, pelo fato de a tradução da mesma não corresponder ao original. Especificamente, o "you" que se refere a Odisseu foi traduzido como "vocês", o que incluiria Telêmaco, em detrimento da força da acusação contra Odisseu. 


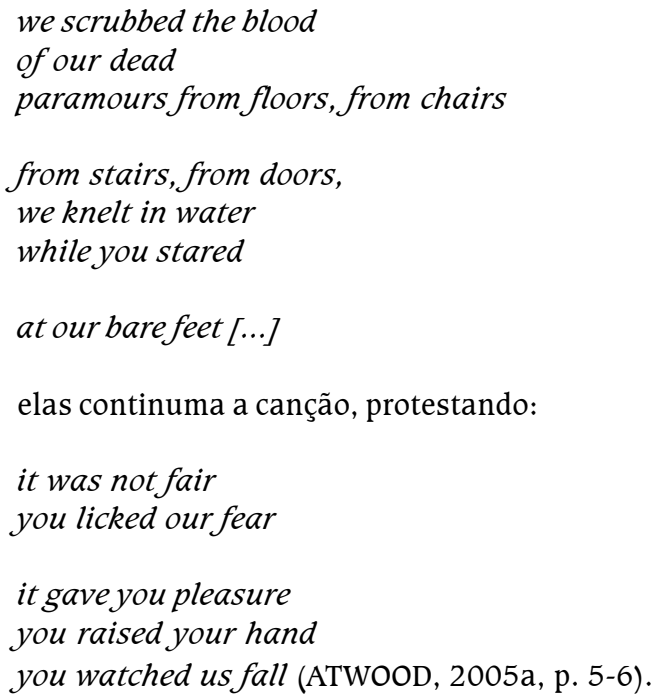

Transparece aqui novamente a opressão exercida por Odisseu sobre as escravas supostamente traidoras por terem se deitado com os pretendentes e, portanto, não tinham direito à vida, pois, como objetos de propriedade de Odisseu, como rei e senhor, não tinham permissão para se deitar com outros homens. Sua canção termina com a repetição de "we danced on air/ the ones you failed/ the ones you killed" das estrofes anteriores, desta maneira enfatizando o fato de elas se sentirem traídas por Odisseu, como "to fail" implica, ao serem condenadas à morte por ele e subsequentemente enforcadas, "dançando no ar", ironizando grotescamente sua própria morte.

Esses dois primeiros capítulos já estabelecem que, tanto a narrativa de Penélope - como "arte menor" em relação à arte maior de Homero -, quanto à canção das escravas - sem a dimensão e amplidão de um poema épico, pois o próprio título, "Canção para pular corda", já pressupõe uma canção de criança -, estão em contraponto paródico com a Odisséia. Além disso, a canção das escravas, apesar de escrita em dez tercetos, não tem pontuação, mostrando assim como elas não estão valorizando a formalidade da escrita masculina; a rima às vezes é perfeita, outras vezes imperfeita, ou até inexistente; o fato de usarem linguagem vulgar, por serem escravas, confirma, por um lado, seu status social, iletradas e sem cultura para poderem se expressar melhor e, por outro, novamente parodia o estilo épico elevado. Além disso, esta canção acusatória antecipa seu enforcamento como será narrado por Penélope em "Odisseu e Telêmaco matam as escravas" - e também sua acusação final, em " $\mathrm{O}$ julgamento de Odisseu, gravado pelas escravas". 
Em contraponto ao capítulo III - "Minha infância" - no qual Penélope narra sua descendência do rei Icário e de uma náiade, caracterizando assim sua alta estirpe ${ }^{3}$, no capítulo seguinte as escravas apresentam o lado avesso da estrutura social vigente. Como o próprio título já revela, "Choro de criança, um lamento", elas cantam:

Também éramos crianças. Também nascemos dos pais errados. De pais pobres, pais escravos, pais camponeses e pais servos; pais que nos venderam, pais de quem nos roubaram. Nossos pais não eram deuses, não eram semideuses, não eram ninfas nem nereidas. Fomos servir no palácio, desde pequenas; trabalhávamos duramente, dia e noite, desde pequenas. Quando chorávamos, ninguém enxugava nossas lágrimas (...). Diziam que éramos vadias. Diziam que éramos sujas. [...] Se nossos donos, seus filhos, um nobre visitante ou os filhos dele quisessem deitar conosco, não poderíamos recusar. [...] Isso tudo aconteceu conosco quando éramos crianças. [...] Moíamos a farinha para casamentos espetaculares, depois comíamos os restos; jamais teríamos uma festa de casamento para nós, ninguém trocaria presentes caros por nossa causa; nossos corpos pouco valiam. Mas queríamos cantar e dançar também, queríamos ser felizes também (ATWOOD, 2005, p. 24-25)

O Lamento, como expressão formal de profunda tristeza ou pesar pela perda de uma pessoa ou posição inclui, entre seus tópicos, também o contraste entre passado e presente, queixas sobre a crueldade da fortuna e a inutilidade da vida (PREMINGER; BROGAN, 1993, p. 675). Desta maneira, o Lamento das escravas contrapõe não apenas sua infância a de uma mulher pertencente à classe senhorial, como Penélope, mas também a tudo o que isso implicava: vendidas pelos próprios pais aos senhores, ou roubadas pelos mesmos, submetidas desde pequenas ao trabalho escravo e, portanto, também ao binômio sexo-poder, seus corpos, como objetos de troca, não tinham valor, antecipando assim a ação vil cometida por Odisseu contra elas. Mesmo assim, elas também queriam cantar, dançar e ser felizes, se bem que sua "felicidade" sempre dependia da "bondade" dos senhores aos quais estavam submetidas. É apenas após sua morte que elas cantam e dançam por meio do Coro. Este Lamento das escravas, expondo a alteridade das mesmas como meninas/mulheres-objeto, cuja única insubordinação consistia no "esgar secreto", em "encontrar rapazes atrás dos chiqueiros", em cuspir "nos pratos antes de servi-los" (ATWOOD, 2005,p. 25), cria um contraste, portanto, entre a vida oficial e a oculta no palácio; revela também

3 Mesmo assim, seu pai ordenou que a atirassem ao mar, por temer que uma profecia do oráculo se concretizasse, afirmando assim seu poder de pai e rei. Sua mãe, apesar de linda, tinha um coração duro e esquecia-se frequentemente da existência da filha, o que levou Penélope a aprender muito cedo "as virtudes da autossuficiência", que lhe serão tão úteis no futuro, quando adquirir a própria identidade. 
a desconstrução, em prosa, do Lamento como expressão formal em verso ou canção - como o lamento de Aquiles sobre a morte de Pátroclo na Ilíada - confirmando deste modo uma "écriture féminine" (CIXOUS, 2000, p. 254) que traz à tona sua voz, suprimida pela homérica.

A próxima intervenção do Coro, no capítulo VIII, é novamente precedida por três outros capítulos narrados por Penélope: no primeiro, ela discute, entre outros assuntos, sua prima Helena de Troia ${ }^{4}$, a mulher que ganhou fama "por atos escandalosos, principalmente de natureza sexual", pois Helena "só se destacou pela infâmia" e "jamais foi punida, por nada" (ATWOOD, 2005, p. 29-31), ao passo que ela própria concretiza o tipo de mulher devotada ao marido, esperando por sua volta, enquanto cuida de suas propriedades e do filho, deste modo evidenciando o contraste, mas também a similaridade entre dois tipos de mulheres que, mesmo rainhas, continuavam a ser mulheres-objeto, mesmo que em outro nível que o das escravas.

No capítulo seguinte, Penélope comenta como seu casamento foi

arranjado. Faziam as coisas assim, naquela época. [...] Pela antiga lei, só pessoas importantes casavam, pois apenas as pessoas importantes tinham herança. No mais, ocorriam coitos de vários tipos - sedução ou violentação, casos amorosos ou encontros de uma noite com deuses que se diziam pastores ou pastores que se apresentavam como deuses (ATWOOD, 2005, p. 32)

corroborando assim não apenas que o estupro das escravas pelos senhores fazia parte do classismo e da dominância masculina vigentes na época, pois eram oprimidas por serem escravas e mulheres, como também evidencia a noção da "noiva-como-dote" para mostrar como as mulheres, como objeto de troca, consolidam e definem o vínculo social entre os homens (RUBIN apud BUTLER, 2003, p. 222). Esta noção transparece também na exposição que Penélope faz deste "arranjo", camuflado por um torneio:

Na corte do rei Icário, meu pai, ainda conservavam o antigo costume de promover torneios para saber quem deveria desposar uma moça nobre que estivesse - por assim dizer - no mercado. O vencedor do torneio ganhava a mulher e a festa de casamento, depois deveria morar no palácio do pai da noiva e contribuir com sua parcela de rebentos masculinos. Ele obtinha riquezas por meio do casamento [...] (ATWOOD, 2005, p. 34-35)

\footnotetext{
${ }^{4}$ Como Penélope comenta o fato de Helena ser filha de Zeus, que assumiu a forma de cisne para seduzir sua mãe, "os deuses pelo jeito não conseguiam manter mãos, patas ou bicos longe das mulheres mortais, estavam sempre violentando uma ou outra" (ATWOOD, 2005, p. 30), confirmando assim como o patriarcado e a dominância masculina reinavam também entre os deuses.
} 
Este arranjo é confirmado no próximo capítulo, quando ela é "entregue a Odisseu, como um naco de carne [...] embrulhada em ouro", enquanto no banquete de seu casamento, os pretendentes malsucedidos "comportavam-se como se tivessem deixado de arrematar um cavalo em leilão" (ATWOOD, 2005, p. 44-45), corroborando mais uma vez seu valor de "noiva-como-dote".

Deste modo, quando o Coro retorna, cantando "Se eu fosse princesa, uma canção popular", a primeira estrofe, apresentada por uma das escravas

\begin{abstract}
Se eu fosse princesa, cheia de prata e ouro, Amada por um herói, jamais envelheceria; $\mathrm{Ou}$, se um jovem formoso me desposasse, Linda, feliz e livre eu sempre seria!
\end{abstract}

Já demonstra que este desejo também é uma utopia, pois Penélope, mesmo princesa, "cheia de prata e ouro" - como Helena - e "amada" por Odisseu, é feliz por pouco tempo, pois ele parte para Troia quando Telêmaco tinha um ano e, como rainha e mulher, ela é constantemente vigiada. Em contraposição ao sonho, a vida sofrida das escravas é apresentada por outra escrava na estrofe seguinte, na qual são enfatizadas sua submissão, servilidade e carência:

Apanho e levo sempre, ouço tudo e faço,

É "sim senhor" e "não senhora" dia após dia.

Por baixo do sorriso escorre a lágrima,

Enquanto arrumo a cama fofa da paz alheia.

Já a terceira escrava clama pelo término deste ordálio

Ó deuses e profetas, chega desta vida!

Que um belo herói me queira como consorte!

Mas ninguém quer saber de mim, pobre coitada.

Meu fado é o trabalho, meu destino a morte.

Prenunciando assim o próprio final de todas elas e sua posterior invocação às Fúrias, pois os deuses não as ouviram.

A primeira e a última estrofes, por sua vez, vêm seguidas de um estribilho no qual o Coro, em conjunto, consola e aconselha a essas escravas

Siga então, senhora, por longas vagas,

Sobre a água fria feito cova escura

Que engolirá talvez seu barco azulado,

Pois à tona nos mantém só nossa fé mais pura. (ATWOOD, 2005, p.

$52-53)$ 
Pressagiando, outrossim que, assim como apenas a fé numa vida melhor mantém seu pequeno barco azul à tona, é esta mesma fé que as fará retornar, como vingadoras, levando a sua redenção.

Se a "canção" designa toda composição poética destinada ao canto, o fato de se tratar de uma "canção popular" já demonstra seu contraste com a canção erudita, que se caracteriza pela obediência a esquemas cultos e precisos (MOISÉS, 1999, p. 68). Assim, esta canção, apesar de escrita em cinco quartetos de rimas emparelhadas, por estar acompanhada de "violino, acordeom e apito" já evidencia uma mistura de instrumentos musicais cultos e populares, o que acentua a mistura de diferentes formas literárias na obra, ressaltando mais uma vez uma voz feminina que desconstrói o estilo épico homérico. O fato de as escravas fazerem uma mesura, ao final, enquanto uma delas passa o chapéu, agradecendo, demonstra ainda tratarse de uma apresentação pública.

A próxima apresentação do Coro, em "O nascimento de Telêmaco, uma pastoral", vem novamente precedido pela narrativa de Penélope: sua viagem marítima a Ítaca, sua chegada ao palácio real, onde todos queriam vê-la, "prova inegável de que Odisseu cumprira sua missão, trazendo uma esposa nobre e os valiosos presentes que a acompanhavam"(ATWOOD, 2005, p. 55), confirmando seu valor de "noiva-como-dote". Entretanto, apesar das atenções de Odisseu, ela chora muito. Por outro lado, Euricléia, a antiga aia de Odisseu, não a deixa fazer nada pelo marido, pois sua função era engordar para dar "um filho grande e forte a Odisseu!", demonstrando assim que, se por um lado o corpo da mulher "simboliza os processos de reprodução, enquanto a sua tarefa de cuidados filiais a liga per se ao lar e à natureza" (BONNICI, 2007, p. 66), a função atribuída a Penélope era apenas a de procriação, pois até o encargo de cuidar de Telêmaco, após seu nascimento, foi-lhe tirado por Euricléia, cujo amor pelo menino "era infinito" (ATWOOD, 2005, p. 60).

E é exatamente o nascimento de Telêmaco que dá ensejo ao Coro de se manifestar, desta vez através de uma "pastoral". Entretanto, se a pastoral é um poema que descreve cenas ou acontecimentos pastorís ou qualquer episódio ou cena de encanto idílico, este "idílio" - em sete estrofes de comprimentos variáveis, confirmando portanto não se tratar de um gênero poético definido (CUDDON, 1992, p. 442) -, na realidade contrasta a gestação, nascimento e infância deste príncipe com o das escravas, desta maneira transformando o "idílio" em relação ao príncipe em pesadelo, em se tratando delas. Pois Telêmaco

Por nove meses [...] singrou os mares rubros do sangue materno Para fora da gruta da noite escura, do sono, Dos sonhos perturbadores ele saiu 
RENAUX, S. P. M. L. S. DA Odisséia À OdisséIA de PenÉlope..

Em seu bote frágil, o bote de si mesmo,

Pelo arriscado oceano de sua vasta mãe ele navegou [...]

Enquanto elas, já antecipando seu final pelas mãos do príncipe, enfatizam, através de um paralelismo de contraste com a gestação de Penélope como rainha, a gestação de suas mães escravas e portanto sem nenhuma capacidade deliberativa sobre seu corpo:

[...] as doze que morreríamos por suas mãos

Sob o comando de seu pai implacável

Navegamos também nos escuros botes frágeis, de nós mesmas

Pelos mares turbulentos de nossas mães inchadas de pés lanhados Que não eram rainhas, mas um grupo variado mestiço,

Compradas, trocadas, capturadas, raptadas de servos e estranhos.

E, ao comentarem seu nascimento, sua alteridade como escravas é ainda mais realçada, pois

Atracamos ao mesmo tempo que ele $[\ldots]$

Impotentes como ele, mas dez vezes ainda mais impotentes,

Pois seu nascimento foi ansiado e festejado, e o nosso não.

Como elas continuam expondo sua objetificação,

Sua mãe ofertou um príncipe. Nossas diversas mães

Desovaram apenas, pariram, puseram ovo, expeliram, partejaram,

$[\ldots]$

Éramos jovens animais, para sermos dispostas à vontade,

Vendidas, afogadas no poço, trocadas, usadas, descartadas quando fenecidas.

Ele tinha pai; nós simplesmente aparecemos [...]

Elas destacam uma vez mais a sua marginalidade, por não terem pai reconhecido, e a força do poder masculino e do patriarcalismo.

Mesmo assim, suas vidas

Estavam enredadas na dele; também éramos crianças

Quando ele era criança,

Éramos seus brinquedos e mascotes, [...]

Crescemos enquanto ele crescia,também rimos, corremos como ele corria, $[\ldots]$

Ele nos via como coisa sua, para fazer o que bem entendesse,

Para cuidar dele, alimentá-lo, lavá-lo, diverti-lo,

Embalá-lo até que dormisse no perigoso bote de nós mesmas. 
Sem imaginar que este mesmo menino com quem brincavam e a quem serviam seria seu futuro algoz, tornando assim o ato vil do príncipe ainda mais perverso. Como a estrofe seguinte novamente corrobora,

Não sabíamos, quando brincávamos com ele na areia

Da praia de nossa ilha pedregosa [...]

Que aquele se destinara a ser nosso frio algoz adolescente.

E perguntam, retorica e ironicamente:

Se soubéssemos, teriamos feito com que se afogasse, no início? $[\cdots]$ Teriamos tido coragem?

Elas encerram a canção dizendo à plateia

Pergunte às Três Irmãs, a fiar seus labirintos rubros,(...)

Só elas conhecem nosso coração.

De nós você não obterá respostas. (ATWOOD, 2005, p.62-5)

Resgatando assim também a revelação de Odisseu a Penélope, de que "quem soubesse penetrar no coração dos homens e conhecer seus segredos estava no caminho certo para dominar as Parcas e controlar o fio de seu próprio destino" (ATWOOD, 2005, p. 56). Este comentário evidencia que Odisseu não conhecia o coração das escravas que iria mandar executar e, consequentemente, também não iria controlar o fio de seu próprio destino após a morte, pois elas irão persegui-lo eternamente, como será constatado na última aparição do Coro.

Desta maneira, o Coro das escravas vai aos poucos tecendo sua própria história, na qual a violência cometida contra elas já se iniciara no ventre materno, enquanto sua objetificação como brinquedos e servas de Telêmaco apenas confirma como sua futura vitimização por parte do filho de seu senhor estava já enraizada em sua infância.

Prossegue agora a narrativa de Penélope, desta vez concentrandose no episódio que deflagrou a Guerra de Troia: a "vaidade, egoismo e luxúria depravada" de Helena, que, ao fugir com Páris para Troia, ultrajou a "honra familiar" de Menelau e de seu irmão Agamemnon. Enfurecidos, eles exigiam tanto o retorno de Helena quanto do tesouro que ela havia levado, evidenciando assim como também Helena foi uma "noiva-como-dote", objeto de troca, consolidando o vínculo social entre os homens e concretizado especificamente no pacto que Odisseu fez com os outros pretendentes à mão de Helena: "defender os direitos de Menelau" (ATWOOD, 2005, p. 70-71), 
"caso algum homem tentasse tirá-la de seu marido" (ATWOOD, 2005, p. 41-42).

Já no capítulo seguinte - "Espera" -, Penélope comenta as informações que recebia sobre a guerra de Troia, como "os menestréis entoavam canções sobre os heróis mais notáveis", enquanto ela aguardava apenas notícias sobre Odisseu (ATWOOD, 2005, p.75). E, após a queda de Troia, não recebe mais notícias, apenas rumores contando das aventuras de Odisseu e seus homens durante os dez anos seguintes, enquanto os menestréis "cantavam sempre a versão mais nobre" na presença dela, pois "só um poder divino superior" poderia evitar que seu marido voltasse correndo a seus braços (ATWOOD, 2005, p.76-77).

Cuida "sozinha da imensa riqueza de Odisseu. Não havia sido preparada para a tarefa, durante sua vida em Esparta. Afinal, era uma princesa, o trabalho cabia aos outros" (ATWOOD, 2005, p. 77), evidenciando novamente o classismo, a estratificação social que reinava na época juntamente com o patriarcado. Mesmo assim, Penélope aprende a fazer inventários, a organizar os cardápios e o guarda-roupa do palácio, além de instruir as fiandeiras e tecelãs. Adquire reputação de esperteza nos negócios. Sua política "priorizava o aumento da riqueza de Odisseu" e assim, quando ele voltasse, ela the revelaria seu "sucesso nas atividades consideradas masculinas", deste modo demonstrando uma argúcia que lhe será útil ao usar do subterfúgio da mortalha para afastar os pretendentes que irão se aproximar.

Revela também como "os escravos não podiam dormir com as escravas sem permissão" antecipando a justificativa usada por Odisseu como rei e senhor dos escravos -, para condenar as escravas à morte. Por outro lado, como esses escravos por vezes "se apaixonavam e sentiam ciúme, assim como seus patrões", Penélope era obrigada a vender o escravo, mantendo apenas e criando pessoalmente "uma bela criança" que eventualmente nascesse desses encontros, ensinando-a a "ser uma escrava refinada e agradável" (ATWOOD, 2005, p. 79-80), evidenciando desta forma o apego que chegou a ter pelas doze escravas enforcadas e o baque sofrido ao saber de sua execução.

Enquanto isso, continuam chegando "novos boatos" sobre Odisseu: alguns, consolidando sua imagem heroica e aventureira; outros, mostrando a real dimensão de suas aventuras. Por esta razão, quando o Coro retorna com a canção "Um capitão astuto, uma nau precária", as escravas, em trajes de marinheiro representando os marujos que acompanharam Odisseu em sua volta de Troia, apresentam a desconstrução paródica das aventuras de Odisseu e, consequentemente, sua imagem homérica, em contraponto às canções encomiásticas dos menestréis. Como o primeiro dos quinze quartetos 
rimados já revela

O grande Odisseu zarpando de Tróia,

Traz o coração e o barco cheios de jóias, Pois ele era o querido da deusa Atena,

Sempre a mentir, a roubar e a iludir.

Temos um gradual desmascaramento da figura de Odisseu: grande quando zarpa de Troia, com sua pilhagem no barco e no coração, pois contava com o auxílio de uma deusa; entretanto, este mesmo "ardiloso Odisseu", como os menestréis o descreviam, é retratado pelas escravas/ marinheiros como "sempre a mentir, a roubar e a iludir".

Os quartetos seguintes vão sucessivamente narrando-sempre em tom paródico - suas aventuras em Lótus, na terra do Ciclope, a consequente maldição de Posídon, "sempre no encalço enquanto ele singra os mares", os vis lestrigões, a ilha de Circe, sua parada na Ilha dos Mortos, a atração das sereias, o redemoinho de Caribdes e Cila, o perecimento dos marujos na tempestade enquanto ele estava na ilha de Calipso, sua escapada após "sete longos anos de beijos e abraços", sua chegada à ilha de Nausicaa, terminando com o comentário:

Ele contou suas aventuras e juntou a sua história Centenas de mortes e dores sofridas, Ninguém sabe dizer o que o destino reserva, Nem Odisseu, um mestre em disfarces! (ATWOOD, 2005, p. 85)

Esses quartetos ainda vêm entremeados pelos refrões

Um brinde ao capitão, tão livre e galante!

Preso numa pedra, pendurado na árvore,

Ou nos braços gentis de uma ninfa marinha,

Onde todos marujos queríamos estar! (estrofe V)

Então, saúde ao capitão, onde quer que se encontra, Jogado para cá e para lá pelo imenso oceano,

Sem a menor pressa de chegar em casa -

Odisseu, o velho rabugento ardiloso! (estrofe VIII)

Um brinde ao nosso capitão, onde quer que esteja, Caminhando sobre a terra ou perdido nos mares, Pois não está cá no Hades, ao contrário de nós E disso vocês não tirarão o menor proveito! (estrofe XV) (ATWOOD, 2005, p. 85-86). 
Entretanto, se o "brinde ao capitão" já parodia a admiração que seus marujos sentem por ele; se "saúde ao capitão" desconstrói sua figura heroica ao ser apresentado como "velho rabugento ardiloso"; e se a repetição "um brinde ao capitão", que continua perambulando pela terra e pelos mares, prefigura a perseguição que as escravas farão a ele, estes refrões são ainda complementados por epítetos, formando outro paralelismo de similaridade, ao elas o chamarem "Odisseu, o mais salgado marujo!", "Odisseu, o épico masculino!", "Odisseu, o mais esperto dos trapaceiros!", "Odisseu, um mestre em disfarces!", enquanto ele próprio se gaba para o Ciclope de ser "Odisseu, rei dos logros!", deste modo contribuindo para a desconstrução paródica de sua imagem homérica.

A próxima apresentação do Coro é outra vez precedida por três capítulos narrados por Penélope. No primeiro, "Os pretendentes se empanturram", Penélope relata seu encontro, nos campos elíseos, com Antino - primeiro pretendente morto por Odisseu -, que lhe revela o real motivo dos pretendentes à sua mão: o tesouro e o reino. Esta ambição confirma o comportamento abusivo e hipócrita dos mesmos no palácio de Odisseu, matando animais para comer, mandando nas escravas, fingindo admirar a beleza, competência e sabedoria de Penélope. As escravas, entretanto, como espiãs da rainha, contam a ela o que eles diziam enquanto serviam carnes e vinhos, para ajudá-la a pensar em como detê-los, razão pela qual Penélope, posteriormente, também se sentirá culpada pela morte delas, como será visto.

Em "A mortalha", narra como a pressão dos pretendentes aumenta, enquanto seu filho a acusa de ser responsável pela dilapidação da herança. Ardilosa como Odisseu, pensa então num estratagema para enganar os pretendentes: confeccionar uma mortalha para Laertes, seu sogro, antes de escolher novo marido. Desta maneira, por mais de três anos, Penélope desfaz o tecido à noite, com as doze escravas - as mesmas que ela havia comprado ou recebido quando eram bebês, que brincaram com Telêmaco e que foram por ela "cuidadosamente treinadas para desempenhar as tarefas do palácio. Eram moças agradáveis, cheias de energia; faziam algazarra e riam alto às vezes [...] Tinham lindas vozes, todas elas, e haviam aprendido a usá-las muito bem" (ATWOOD, 2005, p. 97), descrição essa que explica o desempenho delas no Coro: cantando, dançando e declamando. E, da mesma maneira como ajudam Penélope na "tarefa de desconstrução" (ATWOOD, 2005, p. 98) do tecido - tarefa esta que as torna "irmãs" da rainha a fim de enganar os pretendentes -, elas executam, através do Coro, a tarefa da "desconstrução" de Odisseu - simultaneamente sua vingança e redenção perante o mundo helênico e o nosso. 
Entretanto, como Penélope continua, uma delas acidentalmente traiu o segredo do "tecer interminável", pois Penélope havia pedido que elas "convivessem com os pretendentes e os espionassem" e, consequentemente, "os pretendentes violentaram várias moças e seduziram outras", já que "não era anormal que convidados de uma casa rica ou palácio deitassem com as escravas", caracterizando novamente o binômio sexo/poder e a condição objetal das escravas e antecipando a causa de sua condenação por Odisseu, pois, se "os escravos fossem usados dessa maneira sem permissão do dono da casa" esse ato "equivalia a um furto" (ATWOOD, 2005, p. 99).

Em "Sonhos ruins", por sua vez, Penélope mostra sua preocupação com Telêmaco, que "queria afirmar sua autoridade como filho de Odisseu e assumir as rédeas" enfrentando os pretendentes. Estes, consequentemente, pretendem matá-lo quando retornar de sua viagem em busca de notícias do pai. Penélope tem sonhos aflitivos sobre Odisseu e suas aventuras, mas, ao final tem um "sonho reconfortante", ao sua irmã Ifitma lhe revelar que "Telêmaco retornaria em segurança". Entretanto, ao indagar a respeito de Odisseu, a irmã "se recusou a responder e foi embora", o que leva Penélope a comentar que todos os deuses "zombam de nós. [...] Não é a carne e a gordura dos animais que eles gostam de saborear, e sim o nosso penar" (ATWOOD, 2005, p. 104), ressaltando deste modo que, assim como os escravos são objetos dos seus senhores, os mortais são joguete dos deuses, num paralelismo de similaridade que parece anular a distância entre a classe senhorial e a escrava.

Em contraposição aos "sonhos ruins" de Penélope, na próxima aparição do Coro em "Delícias, uma balada", as escravas almejam o sono para poderem sonhar e assim esquecer sua condição objetal em relação aos seus senhores e, em contraposição às aventuras de Odisseu, esquecer suas próprias desventuras. Como elas cantam, nos dois primeiros quartetos,

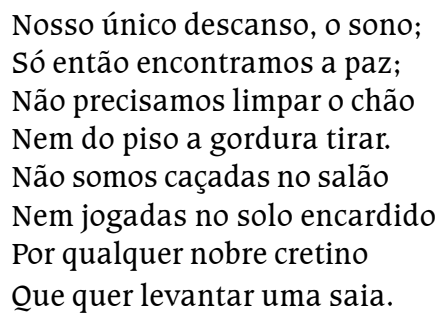

Os próximos quartetos retomam o tema do primeiro - "Se eu fosse princesa" -, apresentando seus anseios por liberdade, beleza e amor infindos: 
RENAUX, S. P. M. L. S. DA OdissÉIA À OdisséIA de PenÉlope...

Quando dormimos queremos sonhar;
Sonhamos que estamos no mar,
Singramos as ondas em barcos dourados,
Tão livres, tão lindas, tão limpas.

Nos sonhos todas nós somos belas

Em vestidos vermelhos rodados;

Dormimos com os homens que amamos,

E os enchemos de beijos gostosos.

Chamamos os homens a nossos barcos dourados

E navegamos até o ano acabar.

Entretanto, se Penélope retorna a sua realidade após sonhos ruins, a realidade das escravas é muito pior, pois significa o retorno a sua alteridade como mulheres-objeto, vítimas da dominância senhorial masculina:

Mas a manhã nos acorda

Novamente trabalhamos, escravas,

E levantamos as saias se mandam,

A qualquer patife ou safado.

Como o texto confirma, as saias - exemplo superficial da diferença entre o mundo feminino e masculino, destinadas a manter as mulheres num estado de permanente acessiblidade sexual (GUILLAUMIN, 2000, p. 101)-, tornam-se assim também simbólicas da diferença de classes e do patriarcalismo, que legitima e perpetua "o poder e a agressão masculina" (BONNICI, 2007, p. 198). Além do mais, o contraste revelado pelo Coro de escravas entre seus sonhos irrealizáveis e a realidade que enfrentam ao acordar, é ainda ressaltado pelo fato de ser apresentado sob a forma de uma balada - composição poética popular antiga, especialmente de caráter romântico, composta em estrofes curtas e acompanhada ou não de música; qualquer canção sentimental ingênua - desconstruindo assim mais uma vez, a nível formal, o meio expressivo da poesia épica, a fim de melhor projetar a alteridade da voz feminina ocultada pela narrativa homérica.

A apresentação seguinte do coro é precedida novamente por três capítulos. Em "Notícias de Helena", Penélope narra como Telêmaco desafia a "autoridade materna ao dizer que não precisava de permissão de ninguém para pegar um barco" e que o "pai sentiria orgulho dele pela demonstração de valentia, por sair da barra da saia das mulheres, que como sempre eram excessivamente emotivas e não mostravam capacidade de julgamento $\mathrm{e}$ raciocínio", deste modo já revelando seu preconceito masculino e antecipando seu cumprimento imediato das ordens de Odisseu em executar as escravas. 
Em "Grito de alegria", Penélope comenta o retorno de Odisseu, após vinte anos, disfarçado de mendigo a fim de avaliar a situação no palácio: os pretendentes dilapidando seu patrimônio, intencionando assassinar Telêmaco, forçando as escravas a serviços sexuais e avançando em sua esposa, justificando assim o extermínio dos mesmos. A rainha revela também sua argúcia ao fingir que não o tinha reconhecido, a fim de preservar a sua verdadeira identidade dos pretendentes; e, se as canções dizem que ela não percebeu nada, ela agora proclama "a verdade": "sabia que o mendigo era Odisseu", deste modo novamente desconstruindo a Odisséia.

Em "Calúnias Perigosas", por sua vez, Penélope argumenta que são "totalmente falsos" os rumores a seu respeito: sobre sua conduta sexual com Anfínomo, de ter se deitado com os outros pretendentes, de não ter punido as escravas indecorosas, pois ela própria também "teria indulgido no mesmo tipo de sordidez", como também a acusação mais séria de que Odisseu não se revelou para ela por desconfiança. Como ela explica, na verdade foi para evitar que ela não o traísse com lágrimas de contentamento. Por esta razão também ele a "trancou nos aposentos femininos com as outras mulheres, quando exterminava os pretendentes", pois ele a "conhecia bem" e sabia que tinha "o coração mole" (ATWOOD, 2005, 118-119), demonstrando assim seu poder sobre a esposa pela sua capacidade de "penetrar no coração dos homens e conhecer seus segredos", capacidade esta que não soube usar, por julgá-la desnecessária, para penetrar no coração das escravas. Deste modo, quando o Coro retorna apresentando "Os perigos de Penélope, um drama", no qual as escravas revelam uma outra face de Penélope, permanece a dúvida em quem acreditar: se na rainha, ou nas escravas.

No Prólogo, Melanto, a de lindas faces, confirma os rumores maldosos sobre Penélope, ao recitar:

\author{
Comentam por aí que Penélope, a puritana \\ Era - quando se tratava de sexo - bela sacana! \\ Alguns afirmam que andava dormindo com Anfínomo, \\ Enquanto fingia dor com choro e muitos gemidos; \\ Outros, que cada um dos rudes pretendentes \\ Teve sua bela chance de se deitar com ela, \\ E o resultado de tantos atos promíscuos, \\ Diz a lenda, foi o nascimento de Pã,o deus. \\ A verdade, senhores ouvintes, nunca é certa - \\ Vamos espiar atrás da cortina! (ATWOOD, 2005, p. 120-121).
}

Se o Prólogo designava, na tragédia grega, a parte anterior à entrada do coro e da orquestra, na qual se anuncia o tema da peça, percebese que no Prólogo citado as escravas apresentam "um outro lance" (ATWOOD, 
2005, p. 120), como o diálogo que a plateia ouve "atrás da cortina" revela: uma Penélope em concluio com Euricléia, no qual a velha ama a adverte da volta de Odisseu e Penélope, após avisar Anfínomo para fugir rápido pela "escada secreta", pergunta a ela: "Quais das escravas estão a par de meus amores?" E, com a revelação de Euricléia

Só doze, minha senhora, que ajudavam, Sabem que a senhora não resistiu aos avanços Dos pretendentes. Elas recebiam os amantes Todas as noites. Conheciam os truques E deixavam a luz acesa - sabem de todos os seus pecados e devem morrer, ou falarão!

Temos a fala mais incriminatória de Penélope, na qual ela pede
Ah, cara ama, então fica por sua conta
Me salvar, e também a honra de Odisseu! [...]
Acuse as escravas de libertinas e desleais,
Apanhadas pelos pretendentes como indevidas presas,
Conspurcadas, vergonhosas, inadequadas
Para servir a um senhor magnífico como ele!

Tornando-a cúmplice do enforcamento das escravas, a fim de manter sua "fama de esposa honesta" (ATWOOD, 2005, p. 122-123). Após este diálogo, o Coro, com sapatos para sapatear, recita, em três quartetos rimados, variações sobre o mesmo tema:

Culpa das escravas!

Aquelas pequenas safadas!

Enforquem todas sem perguntar nada

É tudo culpa das escravas!

Fazendo uma mesura ao final. Esses quartetos paródicos ressaltam, assim, o pedido de Penélope a Euricléia de acusar as escravas como desleais a Odisseu: safadas, grosseiras, fogosas e vadias.

Desta maneira, o meio expressivo deste capítulo, "um drama" no sentido de peça teatral caracterizada por seriedade ou solenidade -, também é subvertido por Atwood, pois, mesmo que o diálogo entre Penélope e Euricléia seja caracterizado pela seriedade, o fato de a peça ser apresentada pelas escravas, em linguagem "vulgar", terminando com um sapateado, já elimina a solenidade da ação representada. Por sua vez o sapateado, como dança popular caracterizada pelo martelar rítmico dos tacões dos sapatos no chão, prenuncia, grotescamente, a dança das escravas ao serem 
enforcadas, e recupera, em contraponto, a "Canção de pular corda", quando elas recitam

$$
\begin{aligned}
& \text { Dançamos leves } \\
& \text { Pés descalços no ar } \\
& \text { No injusto balançar }
\end{aligned}
$$

Demonstrando mais uma vez a íntima relação estabelecida entre conteúdo e forma narrativa.

Os dois capítulos que precedem a próxima apresentação do Coro revelam outras facetas da alteridade feminina e da dominação masculina. Em "Helena toma banho", Penélope recorda seu diálogo com a prima, enquanto esta se dirige ao banho, "acompanhada pela costumeira horda de fantasmas masculinos, todos ansiosos por suas atenções" (ATWOOD, 2005, p. 124), cena que recupera, por um lado, a ideia da mulher que se despe para atrair os homens pela beleza e, contrastivamente, a constatação de que as escravas não tomavam banho e eram, portanto consideradas sujas: "A sujeira era nossa preocupação, nossa responsabilidade, nossa especialidade, nossa culpa", como elas cantam a partir de "Choro de criança".

E, em "Odisseu e Telêmaco matam as escravas", Penélope relata o que Euricléia lhe contou sobre "o tumulto" que aconteceu enquanto dormia: Odisseu tranca as mulheres na ala feminina, observa os pretendentes falharem com o arco que deveria lançar uma flecha através de doze machados, e, depois de ser bem sucedido na empresa, remove disfarce e chacina todos eles. Em seguida, ordena a Euricléia apontar as escravas "desleais", que são obrigadas a lavar e levar os cadáveres para o pátio, a limpar o chão e os móveis. Comanda então Telêmaco a esquartejá-las com a espada, mas este - querendo se afirmar perante o pai e mostrar que era mais rigoroso enforca "todas em seqüência, utilizando uma corda grossa de navio" deste modo recuperando o episódio homérico. Entretanto, na continuação do diálogo entre Penélope e Euricléia, esta revela à rainha quais foram as doze enforcadas: "As impertinentes. As que foram rudes e desleais. As que erguiam o nariz para mim. Melanto, a das belas faces, e suas amigas. A turma. Elas eram todas cadelas descaradas" e "o rei Odisseu não poderia permitir que moças impertinentes como elas continuassem a servir no palácio. Jamais poderia confiar nelas." (ATWOOD, 2005, 128-129). A resposta da velha ama indica claramente como ela está dominada pela visão patriarcal, enquanto Penélope, ao comentar que as escravas enforcadas foram as "violentadas [...] As mais jovens. As mais belas" e que ela se considerava culpada por não haver revelado o esquema da escuta das escravas à velha ama (ATWOOD, 2005, p. 129), está mostrando novamente o lado avesso da história oficial narrada na Odisséia, lado este que será complementado pela "Aula de 
antropologia" que o Coro de escravas apresenta a seguir.

o próprio título deste capítulo desconstrói a noção tradicional de "aula", por ser apresentada por escravas iletradas, conferindo assim à "aula" o significado de exposição feita de maneira informal por alguém que conhece bem o tema que aborda - nesse caso, a Antropologia. Nesta aula, as doze escravas - sempre respondendo às perguntas da plateia - discorrem sobre $o$ que o número doze "sugere às mentes instruídas":

\begin{abstract}
Pois não éramos simplesmente escravas. [...] Sem dúvida tinhamos funções mais importantes que essas. Poderíamos ser as doze virgens, em vez de as doze escravas? As doze virgens selenes, companheiras de Ártemis, a deusa da lua, virginal e mortífera? Poderíamos ser sacrifícios rituais, sacerdotisas devotas que cumpriram seu papel, primeiro entregando-nos aos ritos da fertilidade orgiásticos com os pretendentes, depois ao nos purificarmos, quando nos lavamos no sangue das vítimas masculinas abatidas [...] e renovarmos nossa virgindade, assim como Ártemis renovou a dela [...]? (ATWOOD, 2005, p.131-133)
\end{abstract}

Em função dessa alternativa, elas concluem que seu estupro e enforcamento representam "a destruição do culto matrilinear da lua, por parte de usurpadores patriarcais que defendem um deus-pai. O chefe deles, Odisseu, reclamaria a coroa ao se casar com a suprema Sacerdotisa de nosso culto, ou seja Penélope" (ATWOOD, 2005, p. 133). Desta maneira, as escravas não apenas afirmam seu valor ao sugerir que encarnam as doze virgens da lua, alçando assim seu estupro e enforcamento a uma dimensão religiosa, mítica e cultural ignorado pela narrativa homérica, mas em simultânea contraposição apontam para Odisseu como um usurpador patriarcal, destruidor "do culto matrilinear da lua", reduzindo, portanto mais uma vez sua dimensão heroica. Respondem ainda à pergunta de um "senhor", negando "que esta teoria seja apenas um delírio feminista sem fundamento", pois fatos como estupro e assassinato "certamente ocorreram por toda a região mediterrânea, como as escavações em sítios arqueológicos demonstraram de forma repetida", confirmando assim a credibilidade das informações dadas durante sua apresentação.

Como conclusão ao episódio do enforcamento das escravas, Penélope apresenta, em "Coração de pedra", o que acontece após o relato de Euricléia: mostra sua argúcia ao fingir não acreditar que Odisseu é realmente Odisseu quando o vê e, além disso, argumenta que precisa de tempo "para dominar seus verdadeiros sentimentos a respeito do enforcamento de suas doze jovens escravas". Por esta razão, é censurada por Telêmaco por falta de uma recepção mais calorosa ao pai: chama-a de coração de pedra. Quando 
finalmente finge o reconhecer, após Odisseu passar pelo teste da cama, relatam mutuamente suas aventuras. Mas, como ela diz, ambos mentem. Odisseu parte de novo, para se purificar - evitando a vingança dos fantasmas e parentes dos mortos - e apaziguar Poseidon, "ainda furioso com Odisseu, que cegara seu filho ciclope" (ATWOOD, 2005, p. 138). Uma história convincente, como conclui Penélope, "mas todas as histórias dele eram convincentes". Entretanto, ele se esquece de se purificar das escravas que mandou matar e, assim, não evita sua vingança, que ocorrerá em "Julgamento de Odisseu: gravado pelas escravas".

O título deste capítulo por si só já nos transpõe ao século XXI, ao apresentar o julgamento de um herói homérico gravado em vídeo pelas escravas, fato que será mais uma vez confirmado pelo juiz durante o julgamento. Este se inicia com o Advogado de Defesa de Odisseu, em fala elevada, justificar ao juiz a razão de ele ter matado cento e vinte rapazes que devoravam sua comida, incomodavam a esposa e queriam assassinar Telêmaco, porque Odisseu só teve uma oportunidade de "legítima defesa". Entretanto, a solenidade do julgamento é desfeita no momento que o juiz está "inclinado a concordar", pois logo após o agradecimento do advogado, o juiz pergunta admirado "O que é essa confusão no fundo?" e exclama a seguir, em tom de reprovação: "Ordem! Senhoras, não façam escândalo! Ajeitem as roupas! Tirem as cordas do pescoço! Sentem-se!”. Manifesta assim sua preocupação com a ordem no recinto e com a aparência dessas moças que perturbam a solenidade do julgamento. Estas "senhoras", por sua vez, acusam e exigem: "Vocês se esqueceram de nós! E o nosso caso? Não podem soltá-lo! Fomos enforcadas a sangue frio! Doze de nós! Por nada!" (ATWOOD, 2005, p. 140-141). Mesmo que esta intervenção das escravas com as cordas ainda no pescoço e as roupas desarranjadas torne a cena burlesca, permanece a acusação que elas fazem, de serem ignoradas pela justiça, pois foram mortas sem terem sido culpadas.

O advogado de Defesa, entretanto, responde à nova interpelação do juiz sobre o que ele teria "a dizer em beneficio de seu cliente", afirmando que Odisseu "agia conforme seu direito [...] As escravas pertenciam a ele", "fizeram sexo sem permissão [...] com os inimigos de meu cliente [...]" caracterizando novamente a autoridade da posição masculina e o conceito de mulher/escrava como periférica em relação ao patriarcalismo, tanto por parte de Odisseu, como dele próprio. Entretanto, quando o juiz - unindo parodicamente o passado épico ao presente - consulta a Odisséia como "principal referência para este caso" e, em específico, a rapsódia XXII, e constata não só que "os pretendentes as violentaram. Ninguém os impediu de fazer isso" como também que "as escravas [...] foram obrigadas pelos pretendentes a servi-los em seus propósitos hediondos e revoltantes" enquanto 
Odisseu "sabia de tudo" (ATWOOD, 2005, p.141-142), pergunta ao advogado "Isso é correto?", este exime-se de responder para favorecer seu "cliente". Alega que não esteve presente, pois "tudo isso aconteceu há três ou quatro mil anos" deste modo demonstrando mais uma vez a unilateralidade e preconceituosidade da posição masculina em relação às escravas.

Penélope, entretanto, convocada como testemunha, reforça a acusação das escravas ao confirmar que elas foram violentadas, acrescentando:

$\mathrm{Eu}$ as conhecia bem, meritíssimo. Gostava delas. Praticamente criei algumas das moças. Eram como filhas para mim, como as filhas que nunca tive (Começa a chorar). Lamento por elas! A maioria das escravas acaba sendo violentada, mais cedo ou mais tarde; trata-se de uma característica deplorável, mas comum na vida palaciana. Não foi o fato de terem sido violentadas que as condenou, na mente de Odisseu. Foi terem sido violentadas sem permissão. (ATWOOD, 2005, p. 143-144)

Esta é a fala mais importante de Penélope em favor das escravas, na qual transparece não apenas o laço afetivo que unia a rainha às escravas, mas o fato de que sua violação, tão comum na vida palaciana e dentro do sistema patriarcal, só as condenou por não terem recebido "permissão do dono", uma ironia amarga que caracteriza uma vez mais sua condição objetal.

o fato de que o juiz encerra o julgamento em conluio com o advogado, argumentando que "a época de seu cliente era diferente da nossa. Os padrões de comportamento então eram outros. Seria uma pena que esse incidente lamentável, mas menor, manchasse uma carreira que [...] foi notável" (ATWOOD, 2005, p. 144), reforça a tese de que, para um homem poderoso, um incidente "menor" como esse - a execução de doze escravas não afeta sua carreira.

Entretanto, as escravas exigem justiça e vingança, invocando a presença das Fúrias - doze Eríneas, com cabelos de serpentes, cabeças de cão e asas de morcego - implorando-lhes: "ministrem a punição e a justa vingança em nosso nome! Sejam nossas defensoras, pois em vida não tivemos ninguém!”. E, como castigo, rogam:

Sigam Odisseu aonde ele for! De um lugar a outro, de uma vida a outra, qualquer que seja seu disfarce, qualquer que seja sua forma, persigam-no!Sigam seus passos, na terra ou no Hades, onde quer que busque refúgio, em canções e peças, em grossos volumes e teses,em notas de pé de página e apêndices! Apareçam para ele com nossas formas, nossos corpos enforcados, lamentáveis cadáveres! Que ele jamais tenha sossego! (AWOOD, 2005, p. 145) 
Neste momento culminante do julgamento em que as Eríneas se voltam para Odisseu com olhos vermelhos reluzentes e o advogado de defesa convoca Palas Atena, a protetora de Odisseu, "para defender os direitos de propriedade de um homem, amo e senhor de sua casa, para que leve embora o espírito de meu cliente numa nuvem!" - numa clara referência ao direitos do homem no sistema patriarcal -, novamente a paródia impera: como um deus ex machina, a aparição súbita de Palas Atena "sequestra" Odisseu numa nuvem, enquanto as Eríneas estão no teto latindo e sibilando. Como confirma o juiz, "Mas o que está acontecendo? Ordem! Ordem! Estamos numa corte de justiça do século XXI! Vocês, desçam já do teto! Parem de latir e sibiliar! Senhora, cubra o seio e largue essa lança. O que é essa nuvem? Chamem a polícia! Onde está o acusado? Para onde foi todo mundo?" (ATWOOD, 2005, p. 146), subvertendo, uma vez mais, o meio expressivo da poesia épica.

A próxima aparição do Coro, "Andamos atrás de você, uma canção de amor", é precedida pela última narrativa de Penélope, desta vez sobre a vida doméstica no Hades e sobre as regras a seguir para quem quiser renascer e fazer nova tentativa em vida: beber da fonte do esquecimento, para que as vidas passadas sejam excluídas da memória. Cita como exemplo Helena, que volta sempre e a põe a par das "mudanças na moda" e de "quantos homens arruinou. Impérios caíram por sua causa" (ATWOOD, 2005, p. 148149) perpetuando assim em nossa época a imagem da mulher bela e fútil, da mulher-objeto usando sempre os últimos artifícios da moda. Penélope, por sua vez, não quer beber desta água. Como ela comenta, "Mesmo com meu acesso limitado vejo que o mundo é tão perigoso quanto na minha época, com a diferença de que o sofrimento e a dor acontecem em escala muito maior. A natureza humana continua espalhafatosa como sempre" (ATWOOD, 2005, p. 49), demonstrando, mais uma vez, a capacidade de julgamento de uma pessoa que meditou durante séculos sobre seu destino e sobre o destino da humanidade.

Entretanto, Odisseu continua voltando ao mundo dos vivos, pois, quando Penélope sente que pode perdoar tudo o que ele a fez passar e aceitálo com todos os seus defeitos, "lá vai ele de novo correndo para o rio Lete, para renascer mais uma vez". Como ela reconhece, entretanto, "ele é sincero. Quer mesmo ficar comigo. Chora quando diz isso. Mas uma força desconhecida nos afasta. São as escravas. Ele as vê ao longe seguindo em nossa direção. Elas o enervam. Inquietam. Fazem com que sofra e queira ir para outro lugar, ficar com outra pessoa" (ATWOOD, 2005, p. 150). Por esta razão, Odisseu continua renascendo, seja como "general francês, invasor mongol, empresário norte-americano, caçador de cabeças em Borneu. Já foi astro do cinema, inventor publicitário. Sempre acaba mal, em suicídio, 
acidente, morte no banho ou assassinato, e volta para cá de novo", como ela acrescenta, confirmando através dessas vicissitudes a complementação da vingança e simultaneamente a redenção das escravas, que finalmente ocorre, ao elas o perseguirem por toda a eternidade.

Como elas apresentam, no Coro "Andamos atrás de você, uma canção de amor" (ATWOOD, 2005, p. 152-153), rematando a desconstrução de Odisseu:

\begin{abstract}
Alô! Senhor Ninguém! Homem Sem Nome! [...] Estamos aqui também, nós que não temos nomes. [...] As que carregam a vergonha imputada pelos outros! [...] As servas, as moças sujas de faces rosadas, [...] as que lavam o sangue.[...] Lembra de nós? Claro que sim! Trouxemos água para que lavasse as mãos, lavamos seus pés [...] moemos seus grãos, arrumamos sua confortável cama. Você nos pendurou, nos estrangulou e deixou penduradas feito roupas no varal. [...] Como você se sentiu virtuoso, correto, purificado, depois de se livrar das jovens sujas roliças dentro de sua cabeça! Você deveria ter providenciado um enterro decente para nós. [...] Deveria ter perdido perdão em suas preces. Agora não pode mais se livrar de nós, aonde quer que vá: em sua vida, após a vida ou em qualquer outra vida (ATWOOD, 2005, p. 152-153).
\end{abstract}

Retomando todas suas mágoas e acusações, as escravas ainda o advertem de que sabem "identificar seus disfarces: nos caminhos do dia, nos caminhos da noite, onde quer que vá - estamos sempre atrás de você [...] Jamais o abandonaremos" (ATWOOD, 2005, p. 153), encerrando assim sua "canção de amor" a seu amo e senhor. Uma canção que ressalta mais uma vez a subversão paródica do meio expressivo, pois se canção erudita distribui-se numa série de estrofes de número regular de versos, esta canção, como a de origem popular, é escrita em prosa e é dedicada pelas escravas ao seu senhor mal-amado; e se a canção erudita deve "encerrar um sentimento vibrante, onde transpareça amor, paixão, ou mesmo ódio e vingança, mas onde se sinta que pulsa a alma do poeta" (MOISÉS, 1999, p. 70) essa canção, na qual pulsa a alma das escravas externando seu ódio e vingança em relação a Odisseu, inverte mordazmente o tema de "amor" anunciado no título.

Além disso, assim como a canção erudita culmina numa estrofe menor, correspondente ao envoi da balada, através da qual o poeta dedica o poema à bem-amada ou condensa a matéria das estâncias, também a "canção de amor" das escravas termina com uma "Despedida" - um "Envoi", meia estrofe que finaliza a balada ou o canto real, culminando com um verso que serve de refrão às demais estrofes (MOISÉS, 1999, p.70; 179). Dando voz às escravas pela última vez, estas enviam - como envoi denota - sua 
"despedida”, em três quintetos e um dístico rimados:

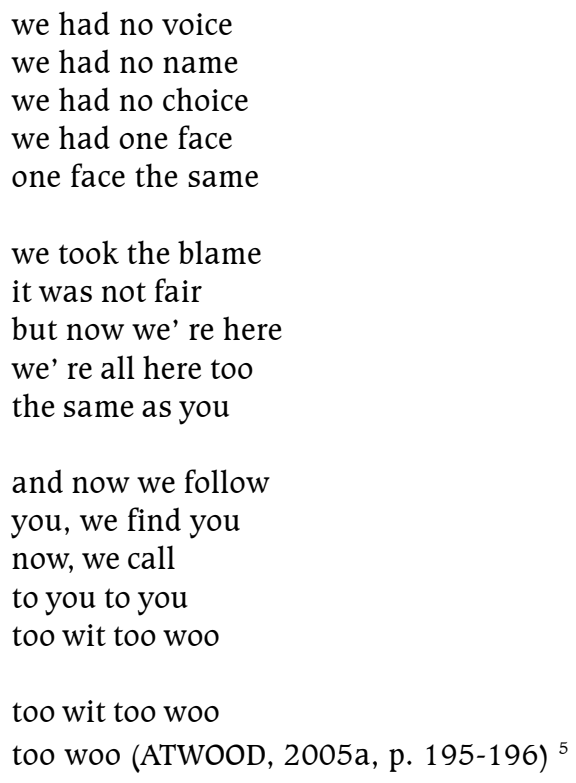

Assim, a primeira estrofe relembra o fato de que não tinham voz, nome ou escolha pela sua condição objetal e de identidade em falta; a segunda rememora a culpa que levaram injustamente pela mesma condição, bem como constata que agora todas estão juntas no Hades, como o próprio Odisseu, fato que demonstra a anulação das barreiras culturais e sociais que as separavam de seu rei e algoz; e a terceira reafirma sua perseguição a ele enquanto o chamam, imitando o piar das corujas - ave que simboliza a morte, a escuridão e a profecia, bem como a falta de nobreza (VRIES, 1974, p. 353-354), como é o caso das escravas. Simultaneamente, como o "envoi" termina gradualmente com o piar de corujas, e a última indicação cênica menciona que "as escravas ganham penas e voam como corujas" (ATWOOD, 2005, p. 196), ressalta-se o fato de que, por estarem no Hades, são todas sombras e portanto não têm voz, como Penélope já havia afirmado em "Uma arte menor":

A dificuldade é não ter boca pela qual falar. Não consigo que me compreendam, não as pessoas do mundo de vocês, do mundo dos corpos, das línguas e dos dedos; [...] quem consegue captar um murmúrio perdido, um grito solto, facilmente confunde minhas

${ }^{5}$ Como na nota de rodapé 2 , optamos por colocar o texto em inglês pelo fato de a tradução não corresponder ao original, deturpando o sentido final do poema. 
palavras com o som da brisa no juncos, morcegos ao crepúsculo, pesadelos (ATWOOD, 2005, p. 17).

Resgatados por Atwood, são estes "murmúrios perdidos" das escravas que a Odisséia não revelou que transparecem através do piar das corujas, fazendo o leitor reavaliar não apenas esse "episódio menor" e obscuro da épica homérica - objetivo primeiro de Atwood, ao entregar a narrativa à Penélope e às doze escravas enforcadas, a fim de contestar e desconstruir parodicamente a autoridade da posição masculina e do sistema patriarcal vigentes. Esses "murmúrios perdidos" também fazem o leitor constatar que a forma narrativa atwoodiana subverte igualmente as convenções e o meio expressivo do gênero épico, reforçando deste modo o impacto das vozes femininas que se contrapõem à voz patriarcal da Odisséia: ao expressar sua indignação e protesto contra todos os paradigmas estabelecidos pela dominação masculina, que as categorizava como mulheres-objeto submissas, resignadas e sem voz - o Coro das escravas torna-se destarte porta-voz não apenas de sua alteridade mas, simultânea e consequentemente, de sua própria redenção.

\section{RESUMO}

A natureza patriarcal da mitologia grega concretizada na odisséia, entre outros, no episódio das doze escravas enforcadas a mando de Odisseu, instigou Margaret Atwood a reescrever a história de Penélope e de suas escravas, baseandose em outras versões míticas. Dando voz a Penélope e às escravas para recontar suas histórias a partir de seu nascimento até a volta de Odisseu e, portanto como narradoras autodiegéticas, a fim de resgatar aspectos não revelados nos textos homéricos, Atwood o faz de um ângulo inusitado: as escravas formam um Coro, que canta, declama e dança enquanto relata sua verdadeira história. Um relato que expõe sua alteridade como sinônimo de condição objetal e de identidade em falta, condição essa que as deixava expostas a todo tipo de violência, levando assim à sua condenação e consequente execução. Entretanto, através do recurso de diferentes gêneros poéticos e estilos, $o$ Coro reconstrói não apenas sua história, mas cria simultaneamente sua própria linguagem - polifônica, paródica, acusadora - desconstruindo assim também a imagem do herói homérico. A redenção das escravas se dá ao levarem Odisseu não só a um julgamento no século XXI, mas principalmente por lhe assegurarem que será eternamente perseguido pelas Fúrias. 
É o relato desse percurso da alteridade à violência e à redenção que será objeto de análise deste trabalho.

Palavras-chave: Margaret Atwood; Alteridade; Violência.

\begin{abstract}
The patriarchal nature of Greek mythology, concretized in the Odyssey, among other instances, in the episode of the twelve hanged maids under Odysseus' orders, has instigated Margaret Atwood to rewrite the story of Penelope and of her twelve maids, based on other mythic sources. By giving the telling of the story to Penelope and to her maids from their birth up to Odysseus' return, and therefore as first- person narrators, in order to bring out unrevealed aspects in the Homeric texts, Atwood does so from an unusual point of view: the maids form a Chorus that sings, chants, and dances while it tells its true story. This account reveals their alterity as synonymous of an objectal condition and of lack of identity, which left them exposed to all types of violence, thus leading to their condemnation and execution. Nevertheless, through the device of different poetic genres and styles, the Chorus reconstructs not only its story but simultaneously creates its own language - polyphonic, parodical, accusatory - in this way also deconstructing the image of the Homeric hero. The maids' redemption occurs as they take Odysseus not only to a trial in the twenty-first century, but mainly by assuring him that he will be eternally followed by the Furies. It is the account of this route from alterity to violence and redemption which this work will focus on.
\end{abstract}

Keywords: Margaret Atwood; Alterity; Violence.

\title{
REFERÊNCIAS
}

ATWood, M. A Odisséia de Penélope: O mito de Penélope e Odisseu. São Paulo: Companhia das Letras, 2005. Books, 2005

The Penelopiad: The Myth of Penelope and Odysseus. Edinburgh: Canongate

BONNICI, T. Teoria e crítica literária feminista. Maringá: Editora da Uiversidade Estadual de Maringá, 2007.

BUTLER, J. Problemas de gênero: Feminismo e subversão da identidade. Rio: Civilização Brasileira, 2003.

CIXOUS, H. Feminine Writing and Women's Difference. In: OLIVER, K. (Ed.). French Feminism Reader. Oxford: Rowman \& Littlefield, 2000. 
RENAUX, S. P. M. L. S. DA OdisséIA À OdisséIA de PenÉlope...

CUDDON, J.A. Dictionary of Literary Terms and Literary Theory. London: Penguin Books, 1992.

GUILLAUMIN, C. The Question of Difference. In: OLIVER, K. (Ed.). French Feminism Reader. Oxford: Rowman \& Littlefield, 2000.

MOISÉS, M. Dicionário de termos literários. São Paulo: Cultrix, 1999.

PREMINGER, A; BROGAN, T.V.F. (Eds.). The New Princeton Encyclopedia of Poetry and Poetics. Princeton: Princeton University Press, 1993.

RENAUX, S. Margaret Atwood e a reinvenção do mito em The Penelopiad. Trabalho apresentado no $2^{\circ}$ Seminário de Literaturas Estrangeiras em Diálogo "Conflito e criação", realizado na FFLCH da Universidade de São Paulo, em 7 de maio de 2008.

VRIES, A. de. Dictionary of Symbols and Imagery. Amsterdam: North-Holland Publishing Company, 1974.

ZOLIN, L. O. Crítica feminista. In: BONNICI, T; ZOLIN, L. O. (Orgs.). Teoria Literária: Abordagens históricas e tendências contemporâneas. Maringá: Editora da Universidade Estadual de Maringá, 2005.

Submetido em: 18/10/2008

Aceito em: 10/08/2009 